\title{
Pemilos : Implementasi Pembinaan Kesadaran Konstitusi di SMK N 1 Pandak
}

Pemilos : Implementation Of Constitutional Awareness in SMK N 1 Pandak

Regeng a,1

${ }^{\text {a }}$ Guru PPKn SMK N 1 Pandak Bantul, Daerah Istimewa Yogyakarta

${ }^{1}$ regengmangir@gmail.com

\begin{tabular}{|c|c|}
\hline Informasi artikel & ABSTRAK \\
\hline $\begin{array}{l}\text { Kata Kunci: } \\
\text { pemilos, kesadaran } \\
\text { konstitusi, SMK N } 1 \\
\text { Pandak, guru PPKn }\end{array}$ & $\begin{array}{l}\text { Artikel ini bertujuan menjelaskan hasil penelitian best practises tentang } \\
\text { penyelenggaraan pemilihan osis (pemilos), menjelaskan peran guru PPKn dan } \\
\text { menganalisis praktek pembinaan kesadaran konstitusi melalui pemilos di SMK } \\
\text { N } 1 \text { Pandak. Penelitian menggunakan metode penelitian kualitatif deskriptif. } \\
\text { Teknik pengumpulan data berupa observasi, wawancara dan studi pustaka. } \\
\text { Teknik analisa hasil penelitian dengan triangulasi sumber dan data. Hasil } \\
\text { penelitian menunjukkan bahwa penyelenggaraan pemilos mengedepankan } \\
\text { prinsip-prinsip pembelajaran yakni 1) Upaya menyampaikan pengetahuan } \\
\text { tentang Pancasila dan Kewarganegaraan kepada peserta didik di sekolah; } 2 \text { ) } \\
\text { Pewarisan kebudayaan yang memuat nilai-nilai karakter kejujuran, keadilan, } \\
\text { toleransi, penghargaan, mengakui hak dan kewajiban kepada generasi muda } \\
\text { melalui lembaga pendidikan sekolah; 3) upaya mengorganisasikan lingkungan } \\
\text { untuk menciptakan kondisi belajar bagi peserta didik melalui dukungan } \\
\text { penyelenggaraan pemilos; 4) Upaya mempersiapkan peserta didik menjadi } \\
\text { warga negara yang baik untuk terlibat aktif dalam proses menentukan } \\
\text { pemimpin; 5) Proses membantu peserta didik menghadapi kehidupan sehari- } \\
\text { hari sebagai warga negara. Guru PPKn berperan menerjemahkan pemilos } \\
\text { sebagai sarana inovasi model pembelajaran yang dirumuskan dalam tiga } \\
\text { langkah yakni orientasi, implementasi dan capaian pembelajaran. Selain itu } \\
\text { pemilos dapat ditelaah dalam sebuah kajian tentang bentuk pembelajaran } \\
\text { PPKn dengan menggunakan pendekatan Kurikulum 2013 melalui 1) Proses } \\
\text { pendidikan yang mengembangkan kemampuan berpikir tingkat tinggi (Higher } \\
\text { Order Thinking Skill) bagi peserta didik; 2) Pendekatan ilmiah (scientific } \\
\text { learning) yang dilakukan oleh peserta didik dan guru menjadikan guru sebagai } \\
\text { fasilitator bagi peserta didik untuk menemukan pengetahuan baru yang } \\
\text { ditemukan di lapangan melalui pemilos; 3) Model pembelajaran yang } \\
\text { dikembangkan melalui pemilos dapat dikatakan sebagai bentuk Pembelajaran } \\
\text { Berbasis Proyek (Project Based Learning); 4) Pengembangan kemampuan } \\
\text { berpikir kritis, kemampuan memecahkan masalah, kreativitas, inovasi, } \\
\text { kemampuan komunikasi, dan kemampuan kolaborasi peserta didik telah } \\
\text { terbangun melalui pemilos; 5) Pemilos sebagai sarana pembelajaran yang } \\
\text { mampu menguatkan pendidikan karakter. }\end{array}$ \\
\hline
\end{tabular}

Keywords:

Pemilos, constitutional awareness, SMK N 1 Pandak, PPKn teacher

\section{ABSTRACT}

This article explain final best practises research about the organization of student election which is called pemilos, explain the role of PPKn teachers and analyze the practice of constitutional awareness development through pemilos in SMK N 1 Pandak. Research uses descriptive qualitative research methods. Data collection techniques in the form of observation, interviews and literature studies. Analysis of research results by triangulating sources and data. The results of the study showed that the implementation of the election process put forward the principles of learning, namely 1) Efforts to convey knowledge 
about Pancasila and Citizenship to students in school; 2) Cultural inheritance that contains the values of the character of honesty, justice, tolerance, appreciation, recognizing the rights and obligations of the young generation through school education institutions; 3) efforts to organize the environment to create learning conditions for students through the support of organizing Pemilos; 4) Efforts to prepare students to be good citizens to be actively involved in the process of determining leaders; 5) The process of helping students face daily life as citizens. PPKn teachers play the role of translating pemilos as a means of innovating learning models which are formulated in three steps namely orientation, implementation and learning outcomes. In addition pemilos can be reviewed in a study of the form of PPKn learning by using the 2013 curriculum approach through 1) the process of education that develops a higher order thinking skill for students; 2) The scientific approach (scientific learning) carried out by students and teachers makes the teacher as a facilitator for students to find new knowledge found in the field through pemilos; 3) The learning model developed through pemilos can be said to be a form of Project Based Learning; 4) Development of critical thinking skills, problem-solving skills, creativity, innovation, communication skills, and students' collaborative abilities have been awakened through pemilos; 5) Pemilos as a learning tool that can strengthen character education.

\section{PENDAHULUAN}

Indonesia merupakan Negara demokrasi. Demokrasi lahir seiring perjalanan bangsa Indonesia yang mengalami berbagai pergolakan dan peristiwa. Proses demokratisasi pun mengalami pasang surut sepanjang sejarah perjalanan bangsa Indonesia sampai pada saat ini. Setidaknya dalam setiap era mengalami dinamika masing-masing, baik di era orde lama, orde baru, hingga reformasi. Hal ini mengindikasikan bahwa Indonesia sedang mencari formulasi terbaik dari pelaksaan sistem demokrasi itu sendiri. Demokrasi menjadi hal yang sangat krusial bagi bangsa Indonesia karena sistem demokrasi dianggap paling sesuai dengan situasi dan kondisi bangsa Indonesia yang beragam. Maka setiap elemen bangsa mau tidak mau perlu terlibat dalam proses demokratisasi baik dalam posisinya sebagai individu atau warga negara maupun sebagai pihak-pihak yang memiliki tanggung jawab dalam penanaman nilai demokrasi. Oleh sebab itu kesadaran demokrasi perlu ditumbuhkan agar setiap warga negara mengetahui dan menyadari akan nilai-nilai demokrasi. Selain itu negara perlu menjamin perlindungan secara konsitutusi untuk dapat mewujudkan nilainilai tersebut sesuai mandat Pancasila dan UUD 1945.

Perlindungan konstitusi menjadi syarat mutlak untuk dapat mewujudkan citacita negara demokrasi. Negara memiliki peran utama untuk melindungi hak dan kewajiban warga negara. Konsitusi merupakan pijakan dasar negara dalam menyelenggaraan sistem pemerintahan. Penegakan nilai-nilai konstitusi harus dilaksanakan secara adil oleh setiap elemen bangsa. Sebagaimana tercantum dalam tugas utama negara yakni menegakkan keadilan melalui badan-badan peradilan negara (Miriam Budiardjo, 2016 :56). Lembaga negara perlu didukung dengan semangat kebangsaan warga negara dalam 
melaksanakan hak dan kewajibannya. Hak dan kewajiban menjadi satu hal yang penting bagi setiap warga negara yang menunjukkan bahwa jika negara melindungi dan menjamin pelaksanaannya maka negara telah melaksanakan tanggung jawab konstitusional. Berbagai hak dan kewajiban warga negara tertuang jelas dalam UUD 1945 tentang kekebasan untuk menyatakan pendapat, kebebasan berorganisasi, kebebasan memilih dan dipilih, dan seterusnya.

Salah satu wujud upaya pemenuhan hak dan kewajiban warga negara sebagai jaminan konstitusi negara yakni melalui Pemilihan Umum. Pemilihan umum merupakan sarana pelaksanaan kedaulatan rakyat yang berdasarkan pada demokrasi perwakilan. Pemilu juga diartikan sebagai sebuah mekanisme penyeleksian dan pendelegasian atau penyerahan kedaulatan kepada orang atau partai yang dipercayai (Ramlan Surbakti, 2007:181). Penyelenggaraan pemilu hendaknya dilakukan dengan hati nurani tanpa tekanan atau paksaan dari pihak manapun karena jelas bahwa pemilu merupakan sarana implementasi hak dan kewajiban warga negara salah satunya menyoal jaminan hak dipilih dan memilih. Pemilu merupakan salah satu tolok ukur negara demokrasi dengan dicirikan adanya kebebasan berpendapat dan berserikat sebagai wujud partisipasi warga negara (Miriam Budiardjo, 2016: 461). Maka dari itu setiap warga negara sebagai bagian yang turut andil dalam pelaksanaan pemilu hendaknya memiliki kesadaran akan hak dan kewajibannya dalam proses pemilihan umum agar penyelenggaraannya tercapai. Memiliki kesadaran dan pemahaman tentang proses pemilu merupakan hal yang perlu diterapkan bagi warga negara. Proses ini perlu dilakukan sejak dini agar masyarakat memiliki pemahaman utuh terkait berbagai hak dan kewajiban konstitusi. Disinilah diperlukan peran dan kerjasama setiap elemen bangsa untuk memberikan pengetahuan dan penyadaran konstitusi. Proses pendidikan berkonstitusi perlu diwujudkan agar setiap generasi bangsa dari masa ke masa untuk mengetahui dan memahami posisinya sebagai warga negara.

Lembaga pendidikan merupakan salah satu elemen yang mampu mengambil peran cukup besar. Proses pendidikan dilakukan oleh setiap masyarakat baik melalui proses pendidikan formal, nonformal, maupun informal sesuai jaminan penyelenggaraan pendidikan yang tertuang dalam UU No 20 tahun 2003 Sistem Pendidikan Nasional. Lembaga pendidikan bertanggungjawab dalam memberikan pengetahuan, pemahaman, dan praktek penyadaran konstitusi sejak dini bagi peserta didik karena mereka adalah generasi masa depan bagi bangsa. Dalam proses ini maka segenap kegiatan pendidikan di lembaga pendidikan perlu untuk mengintegrasikan tentang upaya pemenuhan hak konstitusi warga negara. Ketika proses pemenuhan hak dan kewajiban warga negara dapat diupayakan melalui Pemilu, maka begitu pula dalam proses pendidikan di sekolah. Sekolah merupakan arena belajar yang akan mempengaruhi proses penanaman pengetahuan dan nilai dalam diri peserta didik. Ditambahkan lagi, sekolah merupakan lingkungan sosial yang akan membentuk kepribadian peserta didik melalui iklim dan budaya yang diciptakan (Daryanto, 2015:4). Peserta didik perlu mendapatkan sarana untuk mempelajari proses pemenuhan hak konstitusi secara sederhana. Maka mewujudkan penyadaran kosntitusi di sekolah dapat dilakukan dengan cara Pemiliha Osis (Pemilos).

Pemilos merupakan cerminan pemilu (KPU Bantul 2017). Melalui pemilos, peserta didik akan memahami arti penting pemilu, mengerti tahapan pemilu, mengerti bagaimana menggunakan hak pilih, dan mengerti tata cara pemungutan suara dalam pemilu. Pemilos dapat dikatakan sebagai bentuk sederhana bagi peserta didik untuk dapat menumbuhkan nuansa belajar nyata tentang praktek kesadaran berkonstitusi. Apalagi jika melihat dari kondisi dan karakteristik peserta didik. Peserta didik di sekolah dalam hal ini SMA/SMK merupakan usia $15-17$ tahun yang mana mereka adalah 
usia menuju pemilih pemula. Pemilih pemula disebutkan dalam UU No 40 tahun 2009 memiliki usia minimal 17 tahun. Maka, pemilos merupakan ajang yang sangat strategis untuk membelajarkan kesadaran kosntisui bagi peserta didik yang notabene juga merupakan calon pemilih pemula. Lebih jauh dijelaskan dalam hasil penelitian bahwa pemilih pemula seringkali mengalami masalah dalam orientasi dan partisipasi politik (Januarti, 2016). Hal ini menyebabkan pemilih pemula sering mengalami disorientasi dalam keterlibatan aktif pemilu. Maka melalui pemilos, peserta didik akan mendapatkan pengalaman yang nyata tentang pemilu di sekolah. Selanjutnya peserta didik secara sadar akan tergerak berpartisipasi aktif dalam pemilu di masyarakat.

Pada proses penyelenggaraan pemilos di SMK N 1 Pandak, tidak lepas dari peran guru. SMK N 1 Pandak merupakan salah satu sekolah di Kabupaten Bantul yang juga menyelenggarakan pemilos sebagai sarana pendidikan dan pembelajaran pemilu. Pemilos di sekolah ini melibatkan peran peserta didik dan guru. Hal ini disebabkan peserta didik merupakan aktor pembelajar yang perlu mendapatkan bimbingan dari guru. Selain itu guru memiliki tugas utama dalam mendidik peserta didik (UU No 14 tahun 2005 tentang Guru dan Dosen). Maka proses pendidikan konsitusi melalui pemilos juga menjadi tanggungjawab guru di SMK N 1 Pandak. Pemilos sebagai salah satu cara sederhana dalam pembelajaran kosntitusi negara berkaitan dengan penyelenggaraan pembelajaran salah satu mata pelajaran yang membahas tentang Pancasila dan Kewarganegaraan yakni Pendidikan Pancasila dan Kewarganegaraan (PPKn). PPKn merupakan mata pelajaran yang penting dalam memberikan pengetahuan, nilai dan praktek tentang nilai-nilai kehidupan bermasyarakat, berbangsa dan bernegara. Maka guru PPKn di SMK N 1 Pandak memiliki andil yang sangat besar dalam membelajarkan konsitusi melalui Pemilos. Apalagi jika melihat saat ini pemberlakuan Kurikulum 2013 yang sangat menekankan pada penanaman pendidikan scientific learning. Proses pembelajaran yang mengutamakan partisipasi aktif peserta didik . Oleh karena itu dapat dijelaskan lebih lanjut tentang pemilos sebagai proses pendidikan berkonstitusi yang dapat diterapkan sejalan dengan pembelajaran PPKn di SMK N 1 Pandak.

\section{METODE}

Penelitian ini menggunakan metode kualitatif deskriptif. Lokasi penelitian di SMK N 1 Pandak, Bantul, Daerah Istimewa Yogyakarta. Menggunakan teknik pengumpulan data berupa observasi, wawancara, dan studi pustaka. Menggunakan sumber primer dan sekunder. Sumber primer diperoleh melalui informan dalam penelitian melibatkan sivitas akademik SMK N 1 Pandak yakni siswa, pengurus OSIS, guru dan Kepala Sekolah. Sumber data sekunder diperoleh melalui berbagai sumber data yang berasal dari KPU Bantul dan Hasil Pemilos di SMK N 1 Pandak. Teknik analisa menggunakan triangulasi sumber dan data.

\section{HASIL DAN PEMBAHASAN Pemilihan Osis (Pemilos) di SMK N 1 Pandak}

Pemilos merupakan sebuah sarana bagi peserta didik di sekolah untuk dapat menentukan pengurus osis. Osis merupakan sebuah Organisasi Siswa Intra Sekolah yang memiliki peran penting dalam mengelola berbagai kegiatan kesiswaan di sekolah. Seperti layaknya negara, Osis merupakan sebuah pemerintahan yang ada di sekolah dan mengatur berbagai aktivitas menyangkut kesiswaan di setiap sekolah. Maka, begitu pentingnya posisi Osis di sekolah, penyelenggaraan pemilos juga menjadi bagian fundamental dalam menentukan sistem organisasi di sekolah. Selain itu Komisi Pemilihan Umum (KPU) di setiap daerah juga memiliki peran dalam mendampingi pemilos di sekolah-sekolah. Maka kerjasama antara sekolah dan KPU merupakan sinergitas program yang positif 
guna mendukung pembelajaran bagi peserta didik di sekolah terutama melalui pemilos.

Begitu halnya di SMK N 1 Pandak. Pemilos yang diadakan pada setiap tahun merupakan upaya untuk menentukan ketua osis yang duduk di kepengurusan osis. Kegiatan pemilos juga mensinergikan antara peserta didik, guru, dan KPU. Pemilos dijalankan oleh peserta didik dengan didampingi oleh guru di sekolah dan dukungan pihak sekolah serta KPU sebagai lembaga pendamping. Hal ini sesuai yang tertuang dalam Buku Panduan Pemilos 2017 yang disusun oleh Komisioner KPU Bantul bahwa KPU Bantul juga mendampingi dan memberikan pelatihan kepada guru serta peserta didik dalam penyelenggaraan pemilos. SMK N 1 Pandak menjalankan pemilos pada setiap tahun. Terakhir diadakan tahun 2017.

Sebelum melaksanakan kegiatan pemilos di SMK N 1 Pandak dilaksanakan berbagai kegiatan yang melibatkan peserta didik, guru dan KPU. Diantaranya sebagai berikut :

1. Peserta didik mendiskusikan terkait calon pengurus osis dan program osis ke depan.

2. Guru memberikan pengetahuan dan materi terkait pemahaman tentang kepemimpinan, pemilu, hak dan kewajiban warga negara melalui materi pembelajaran di kelas dan sosialisasi di lapangan.

3. Sekolah menyiapkan alokasi kegiatan untuk penyelenggaraan pemilos.

4. KPU memberikan pelatihan menyelenggarakan pemilos melalui Training of Trainer (TOT)

Berbagai hal tersebut dilaksanakan di

SMK N 1 Pandak dengan berbagai kreativitas. Seperti ketika peserta didik dalam kelompok-kelompok kecil di sekolah mulai mendiskusikan terkait siapa yang akan duduk dalam kepengurusan osis dan bagaimana program osis ke depan. Begitu pula dengan guru PPKn. Guru PPKn memberikan warna dalam pembelajaran di kelas terutama terkait materi kewarganegaraan dikaitkan dengan proses pemilos. Pemilos dijadikan sebagai contoh-contoh riil yang dapat ditemukan oleh peserta didik untuk mempraktekkan berbagai teori, pengetahuan, nilai dan keterampilan tentang kewarganegaraan.

Pada pemilos tahun 2017, SMK N 1 Pandak menyelengarakan kegiatan tersebut dengan melibatkan seluruh elemen di sekolah. Berikut beberapa hal yang berkaitan dengan penyelenggaraan pemilos di SMK N 1 Pandak tahun 2017 :

1. Pemilos dilaksanakan pada 7 September 2017 di SMK N 1 Pandak.

Kegiatan dilaksanakan secara serentak seluruh SMA/SMK di Kabupaten Bantul pada tanggal tersebut. Di SMK N 1 Pandak terdapat rangkaian kegiatan yang dilaksanakan yakni seleksi baik panitia maupun calon ketua osis, penyampaian visi dan misi, persiapan logistik, serta dilakukan evaluasi pasca pemilos. Berbagai rangkaian kegiatan dilakukan dengan pendampingan guru.

2. Jumlah calon ketua osis yang mencalonkan diri sebanyak 5 orang. Untuk putra sebanyak 3 orang dan putri sebanyak 2 orang yang berasal dari kelas $\mathrm{X}$ dan XI.

Pada proses ini guru memainkan peran yang cukup penting. Motivasi dan rekomendasi guru menjadi hal yang mendukung proses pencalonan peserta didik. Di SMK N 1 Pandak terdapat 5 calon ketua osis yang mencalonkan diri membuktikan bahwa partisipasi aktif peserta didik sangat antusias. Selain itu komposisi calon juga merata. Terdapat calon perempuan dan laki-laki. Hal ini tidak lepas dari peran guru dalam memberikan pemahaman tentang kesetaraan hak untuk dipilih.

3. Panitia terdiri atas ketua, sekretaris, bendahara, PPO, KPPS, Keamanan, Humas, dan Panwaslos. Panitia pemilos berasal dari siswa kelas X dan XI.

Dalam penyusunan panitia, guru memainkan peran dalam memberikan rekomendasi terkait kompetensi panitia. Antusiasme peserta didik juga terlihat saat pelaksanaan tugas-tugas kepanitiaan. Peserta didik memiliki pengetahuan dan kemampuan mumpuni dalam penyelenggaraan pemilos. 
4. Jumlah pemilih suara yang menggunakan suara sebanyak 684 suara. Jumlah seluruh peserta didik di SMK N 1 Pandak sebanyak 695 orang.

Dapat dilihat bahwa partisipasi peserta didik dalam pemilos aktif. Hanya ada sekitar 11 siswa yang tidak memilih dikarenakan sakit dan terpaksa tidak masuk sekolah karena ada kepentingan terkait praktek pengalaman lapangan. Selain itu semua peserta didik sebanyak 684 memberikan suara di bilik suara untuk menentukan calon ketua osis. Hal ini tidak lepas dari proses sosialisasi dan dorongan guru kepada peserta didik untuk menggunakan hak suara.

5. Pendamping penyelenggaraan pemilos adalah Pembina Osis, Guru PPKn, Wakil Kepala Sekolah bidang Kesiswaan.

Pada penyelenggaraan pemilos guru dan pihak sekolah mendampingi. Pembina Osis terlibat dalam tugas teknis, Guru PPKn terlibat dalam pembelakalan pengetahuan, penguatan motivasi dan pendampingan pelaksanaan sehingga pemilos berjalan lancar secara teknis dan berhasil secara substantif. Wakil Kepala Sekolah bidang Kesiswaan bertugas dalam pengalokasian program pemilos sebagai agenda sekolah.

\section{Peran Guru PPKn dalam Sukses Pemilos di SMK N 1 Pandak}

Guru merupakan kunci untuk membangun peradaban bangsa (Rohmadi, 2012). Bangsa yang luhur adalah bangsa yang memiliki generasi penerus yang memegang teguh prinsip-prinsip kehidupan berbangsa dan bernegara serta menjunjung tinggi nasionalisme. Peserta didik di sekolah merupakan bagian dari generasi yang harus siap menerima tongkat estafet kepemimpinan di masa depan. Untuk mencapai hal tersebut, proses pendidikan di sekolah menjadi babak yang sangat menentukan tumbuh kembang peserta didik hingga menjadi pribadi berkualitas. Maka proses pendidikan harus dilaksanakan dengan penuh semangat dan didasari tanggung jawab berbagai elemen sekolah. Guru merupakan salah satu aktor yang memiliki peran penting dalam hal tersebut karena guru selalu berinteraksi dan mendampingi peserta didik dalam kegiatan pembelajaran serta aktivitas di sekolah. Guru harus siap menjadi orang yang selalu terlibat dalam proses pendidikan peserta didik di sekolah.

Begitu halnya dalam Pemilos di SMK N 1 Pandak. Pemilos merupakan sebuah sarana pembelajaran berkonstitusi bagi peserta didik. Selain itu pemilos merupakan sebuah strategi yang sangat relevan dengan tujuan bangsa yakni memiliki warga negara yang sadar dan menjalankan hak dan kewajibannya. Hal ini karena melalui pemilos peserta didik belajar secara nyata tentang proses pemilihan osis yang mana menjadi pemimpin dalam kegiatan mereka di sekolah. Seperti layaknya dalam pemilihan umum untuk menentukan pemimpinpemimpin bangsa yang memutuskan berbagai kebijakan negara sehingga mempengaruhi kehidupan di masyarakat. Sebagai sebuah saran pembelajaran politik di tingkat sekolah, pemilos diselenggarakan oleh peserta didik. Namun, sebagai peserta didik yang masih belajar tentunya peran guru sangat penting untuk membimbing dan mengarahkan jalannya pemilos. Selain itu, kemampuan dan kecakapan peserta didik dalam menyelenggarakan pemilos harus didukung sepenuhnya oleh bimbingan seorang guru. Bagaimanapun mengelola sebuah sistem pemilihan yang sangat menjunjung nilai-nilai keadilan perlu dibimbing dan diarahkan guru sehingga peserta didik memahami dan mampu menjalankan tugasnya dengan baik. Hal ini sesuai dengan tugas utama guru sebagai pembimbing yang tertera dalam UU No 14 tahun 2005 tentang Guru dan Dosen sebagaimana disebutkan guru sebagai pembimbing peserta didik harapannya mampu menuntun perkembangan dengan jalan memberikan lingkungan dan arah sesuai dengan tujuan pendidikan sehingga serta peserta didik dapat belajar memecahkan persoalan atau kesulitan yang dihadapinya. Selanjutnya peserta didik dapat berkembang baik secara fisik dan mental sehingga mampu menjadi pribadi yang berkualitas. 
Proses pendidikan seperti itu tidak hanya akan ditemukan melalui pembelajaran di kelas. Namun jelas bahwa pendidikan pengalaman dan pembelajaran nyata tersebut diperoleh peserta didik dalam kegiatan seperti Pemilos. Maka proses pembelajaran yang berkualitas adalah pembelajaran yang mampu mengintegrasikan berbagai proses pembelajaran sehingga menciptakan sistem pembelajaran yang sinergi dan berkelanjutan. Seperti halnya yang terjadi dalam pemilos di SMK N 1 Pandak. Pemilos di SMK N 1 Pandak bukan dilaksanakan hanya dengan sebuah proses tersendiri saja, melainkan menjadi sebuah model yang dilakukan oleh guru PPKn dengan disinergikan melalui pembelajaran di kelas. Sebagaimana yang disampaikan Oemar Hamalik (2010:57) bahwa beberapa prinsip dalam pembelajaran yakni 1) upaya menyampaikan pengetahuan kepada peserta didik di sekolah; 2) pewarisan kebudayaan kepada generasi muda melalui lembaga pendidikan sekolah; 3) upaya mengorganisasikan lingkungan untuk menciptakan kondisi belajar bagi peserta didik; 4) upaya mempersiapkan peserta didik menjadi warga negara yang baik; 5) proses membantu peserta didik menghadapi kehidupan sehari-hari. Maka, dalam rangka menyukseskan pemilos di SMK N 1 Pandak, guru PPKn menerjemahkan pemilos sebagai sebuah proses belajar bagi peserta didik. Hal ini dapat dijelaskan dalam table di bawah ini:

Tabel 1. Implementasi Prinsip Pembelajaran dalam Pemilos SMK N 1 Pandak

\begin{tabular}{ll} 
No & Prinsip Pembelajaran \\
\hline 1 & Penyampaian pengetahuan
\end{tabular}

\section{Pemilos SMK N 1 Pandak}

Guru PPKn memberikan berbagai pengetahuan tentang Pemilu, Kepemimpinan, Hak dan Kewajiban Warga Negara melalui proses pembelajaran di kelas. Maka proses pemilos berkesinambungan dengan materi pembelajaran tentang kewarganegaraan dan Pancasila yang menjadi muatan dalam mata pelajaran PPKn.

2 Pewarisan kebudayaan kepada Guru PPKn membantu peserta didik dalam generasi muda melalui sekolah memahami nilai-nilai kejujuran, keadilan, toleransi, menghargai antar sesama peserta didik di sekolah melali pemilos.
3 Pengorganisasian lingkungan untuk menciptakan kondisi belajar

Guru PPKn mendampingi peserta didik dalam menyelenggarakan pemilos dengan didukung oleh pihak sekolah. Guru PPKn menjembatani antara pihak sekolah dan panitia pemilos dalam pelaksanaan pemilos yang sukses baik secara teknis pelaksanaan maupun substansi penyelenggaraan. Selain itu guru PPKn memberikan sosialisasi kepada elemen sekolah yang lain agar mendukung pelaksanaan pemilos peserta didik.

4 Mempersiapkan peserta didik Guru PPKn mendorong peserta didik untuk menjadi warga negara yang baik terlibat aktif dalam pemilos baik sebagai panitia maupun peserta. Selain itu memberikan dukungan kepada calon pengurus osis yang dipilih. Maka dalam hal ini guru PPKn memberikan pengetahuan dan pengalaman kepada peserta didik agar dapat menjadi warga negara yang baik dengan penyadaran mengenai hak dan kewajiban memilih dan dipilih. 


\section{Membantu peserta didik menghadapi kehidupan sehari-hari}

Guru PPKn mendampingi peserta didik dalam menjalankan tugas sebagai panitia pemilihan. Hal ini menjadi bentuk nyata implementasi pembelajaran yang dilakukan guru dalam membimbing peserta didik menghadapi berbagai persoalan yang dihadapi. Pada akhirnya peserta didik dapat menemukan cara/strategi dalam menghadapi persoalan.
Pada pola inilah guru PPKn sekaligus mengembangkan model pembelajaran yang inovatif sehingga terjadi kesinambungan antara proses pembelajaran di kelas dan praktek di lapangan. Untuk dapat menjadi guru yang profesional dan berkarakter maka seorang guru harus melakukan kegiatan inovatif yang mendukung pembelajaran dengan berbagai tindakan aktif sebagai berikut 1) membuat ilustrasi; 2) mendefinisikan; 3) menganalisis; 4) mensintesis/menyimpulkan; 5) bertanya; 6) merespon; 7) mendengarkan; 8) menciptakan kepercayaan; 9) memberikan pandangan yang bervariasi; 10) menyediakan media untuk kajian (Mulyasa, 2007). Selain itu model pembelajaran melalui pemilos dapat dikatakan sebagai bentuk Pembelajaran Berbasis Proyek (Project Based Learning) yang menempatkan aspek pengetahuan, pemahaman, pengalaman, keterampilan dan unjuk kerja peserta didik sebagai satu proses yang terintegrasi untuk mencapai tujuan pembelajaran.

Maka berikut ini dapat dilihat model inovasi yang diterjemahkan oleh guru PPKn di SMK N 1 Pandak dalam proses pemilos sehingga menunjukkan bahwa pemilos merupakan sarana inovasi model pembelajaran bagi guru dan peserta didik.

Gambar 1. Inovasi Model Pembelajaran PPKn melalui Pemilos di SMK N 1 Pandak

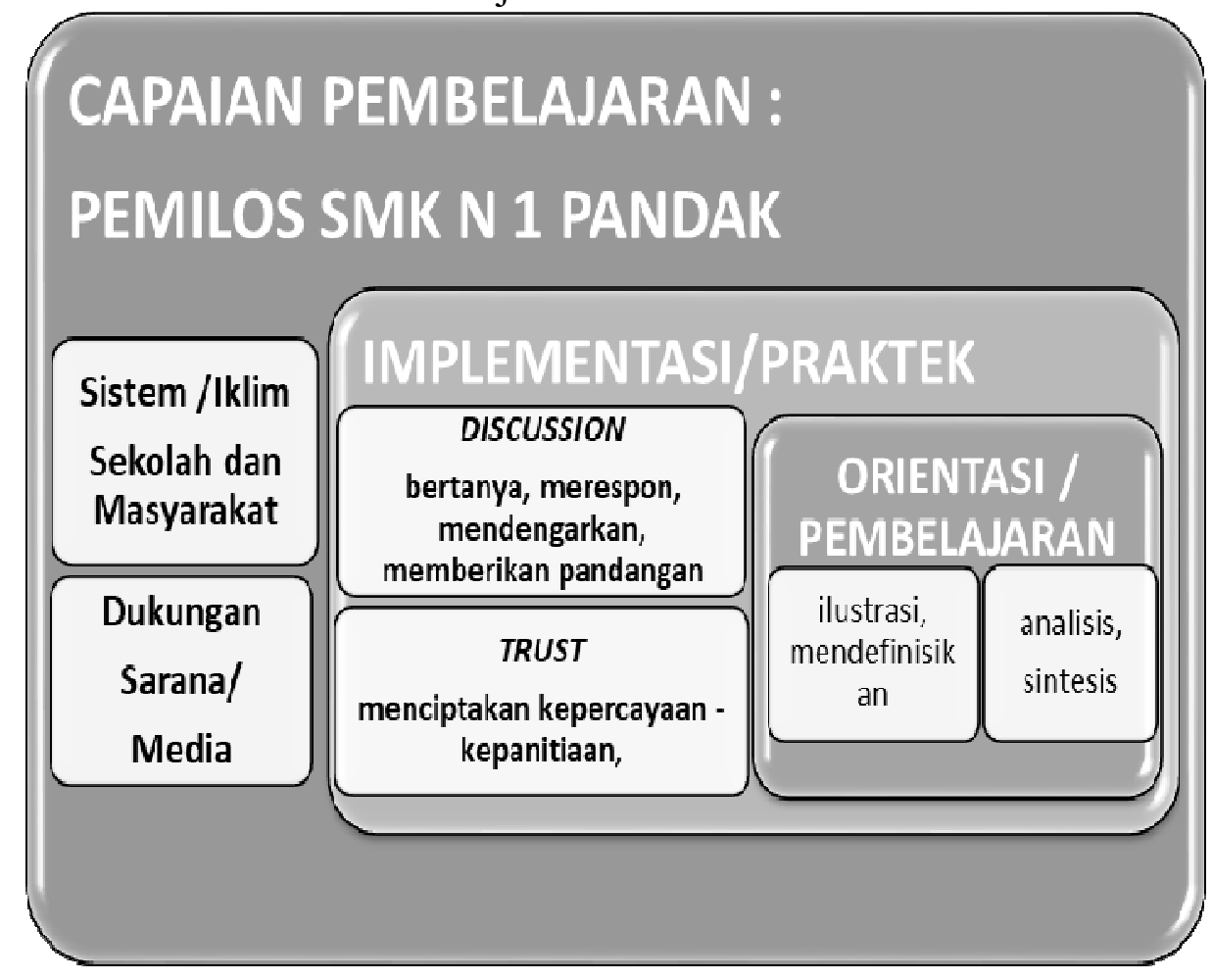


Penjelasan gambar tersebut sebagai berikut. Berbagai tindakan aktif perlu dilakukan dalam menciptakan pembelajaran yang inovatif (Mulyasa, 2007). Maka kegiatan pemilos yang dilaksanakan di SMK N 1 Pandak menjadi strategi yang baik bagi guru PPKn untuk dapat melaksanakan sebuah bentuk inovasi pembelajaran. Guru PPKn berinisiatif untuk menyusun pemilos sebagai sebuah model pembelajaran inovatif dengan prinsip-prinsip berikut ini :

1. Orientasi/ Pembelajaran

Kegiatan pemilos merupakan sebuah aktivitas yang dilakukan oleh peserta didik untuk dapat menentukan pengurus osis yang akan menjalankan tugas untuk memimpin seluruh peserta didik di sekolah. Untuk dapat melakukan kegiatan ini peserta didik perlu memiliki pengetahuan dan pemahaman tentang kepemimpinan, pemilihan umum, organisasi sekolah, hak dan kewajiban warga sekolah, dan lain sebagainya. Maka proses itulah yang dilaksanakan dalam kegiatan orientasi melalui pembelajaran. Materimateri pembelajaran PPKn disampaikan guru dengan variatif untuk memberikan pemahaman peserta didik tentang berbagai hal yang berkaitan dengan kewarganegaraan dan Pancasila. Selain itu terdapat proses analisis dan sintesis berbagai kompetensi yang dimiliki peserta didik. Pada tahap ini guru PPKn memiliki rekam evaluasi prestasi akademik peserta didik sehingga dapat menjadi bahan referensi dan rekomendasi bagi peserta didik untuk terlibat dalam pemilos. Tentunya rekomendasi dari guru sangat mendukung tersusunnya komponen yang cakap dalam proses pemilos.

2. Implementasi/Praktek

$$
\text { Praktek kegiatan pemilos }
$$

dilaksanakan secara nyata oleh peserta didik di sekolah. Melalui pendampingan guru PPKn dan Pembina Osis, peserta didik mendiskusikan berbagai macam hal. Dalam proses inilah guru PPKn memberikan kesempatan kepada peserta didik untuk mendiskusikan berbagai hal yang berkaitan dengan implementasi/praktek pembelajaran yang telah didapatkan di kelas.Guru PPkn bersikap terbuka, merespon pertanyaan peserta didik, bertanya apabila ada hal-hal yang kurang dipahami, sampai pada memberikan simulasi. Selain itu guru PPKn juga bersikap terbuka dalam proses diskusi. Pada akhirnya guru PPKn memberikan kepercayaan kepada peserta didik untuk menjalankan tugas yang telah dirancang.

\section{Capaian Pembelajaran : Pemilos SMK N 1 Pandak}

Pemilos merupakan sebuah capaian pembelajaran dalam hal ini. Pemilos adalah satu kesatuan proses pembelajaran yang dilakukan dengan mengintegrasikan berbagai tahapan yakni pembelajaran di kelas, pembimbingan di lapangan melalui kegiatan praktek dan tindak lanjut pelaksanaan. Dalam hal ini guru PPKn memerankan peran yang strategis dalam melakukan inovasi untuk dapat membangun sinergitas antara berbagai elemen di sekolah dan di masyarakat. Interaksi guru dengan berbagai pihak dalam mendukung kegiatan pembelajaran tidak dapat diabaikan, karena saling berkaitan dan melengkapi (Syaiful Sagala, 2013:185). Guru PPKn berkolaborasi dengan Pembina Osis untuk menentukan proses dan mekanisme yang perlu dilakukan peserta didik. Guru PPKn mendorong pihak sekolah menciptakan iklim/kondisi yang terbuka dan mendukung suasana pembelajaran yang riil kepada peserta didik. Selain itu guru PPKn berkolaborasi dengan masyarakat yakni KPU Bantul untuk memantau dan mendampingi proses pemilos. Maka Pemilos merupakan sebuah capaian pembelajaran inovatif dalam proses pembelajaran PPKn di SMK N 1 Pandak.

\section{Kesadaran Berkonstitusi melalui Pemilos di SMK N 1 Pandak}

Penyelenggaraan pemilos di SMK N 1 Pandak menunjukkan sebuah proses pembelajaran berkonstitusi bagi peserta didik. Kesadaran kosntitusi harus diwujudkan sejak dini kepada setiap warga negara. Proses pemilos di sekolah merupakan ajang yang sangat baik untuk menanamkan pengetahuan 
dan praktek konstitusi kepada peserta didik. Kesuksesan penyelenggaraan pemilos di SMK N 1 Pandak tidak lepas juga dari peran pihak sekolah terutama guru. Guru PPKn memberikan peran yang penting dalam memberikan pengetahuan dan pemahaman tentang kewarganegaraan dan Pancasila. Melalui hal tersebut peserta didik memahami dan menyadari tugas dan tanggung jawab sebagai warga sekolah yang tentunya akan berpengaruh pada tugas dan tanggung jawab sebagai warga negara di masa depan. Sebagaimana yang kita ketahui bahwa peserta didik di usia SMA/SMK merupakan pra pemilih atau pemilih pemula yang perlu mendapatkan pengetahuan dan pengalaman nyata dalam menentukan pemimpin.

Implementasi pembinaan kesadaran berkonstitusi bagi peserta didik dapat ditunjukkan melalui kegiatan pemilos di SMK N 1 Pandak. Berbagai bentuk praktek kesadaran berkonstitusi dapat dijelaskan dengan beberapa hal di bawah ini :

1. Penyadaran hak dan kewajiban warga negara

Bangsa Indonesia menjamin hak dan kewajiban setiap warga negara. Hal ini tertuang jelas dalam UUD 1945 sebagai dasar negara. Jaminan terhadap perlindungan hak warga negara dilindungi oleh konstitusi. Maka setiap warga negara harus menghormati hak dan kewajiban masingmasing. Seperti disebutkan dalam pasal-pasal yang termuat dalam UUD 1945 diantaranya hak memilih, hak dipilih, hak mengemukakan pendapat, hak mendapat pengajaran, hak berkumpul dan berserikat. Berbagai hal tersebut dapat ditemukan peserta didik dalam kegiatan pemilos. Guru PPKn memainkan peran yang sangat strategis dalam hal ini. Pembelajaran materi Pancasila dan kewarganegaraan menyangkut berbagai hal tersebut. Maka Guru PPKn SMK N 1 Pandak telah mengimplementasikan bentuk penyadaran konstitusi kepada peserta didik dengan pembelajaran inovatif di kelas dan pendampingan penyelenggaraan pemilos.

2. Proses Menentukan Pemimpin
Pemimpin adalah seseorang yang akan memimpin jalannya sebuah sistem. Pemimpin suatu negara ditentukan oleh pilihan warga negara. Oleh sebab itu terdapat mekanisme pemilu di Indonesia. Harapanya pemimpin yang dipilih adalah pemimpin yang dimaui oleh masyarakat sehingga mampu membawa aspirasi masyarakat untuk diakomodir dan diwujudkan dalam bentuk kebijakan publik. Guru PPKn memiliki peran vital dalam menjelaskan kepadapeserta didik tentang berbagai teori kepemimpinan melalui pembelajaran di kelas. Sehingga pada proses di masyarakat peserta didik menemukan pengalaman nyata tentang hal tersebut. Melalui pemilos, peserta didik telah mendapatkan pengalaman nyata tentang penentuan dan pemilihan pemimpin. Proses penentuan dan pemilihan pemimpin dijamin dengan konstitusi. Maka pemilos merupakan sebuah sarana bagi peserta didik untuk memahami prinsip dasar pemimpin dalam sebuah sistem pemerintahan negara secara sederhana di lingkungan sekolah.

Hal ini terbukti pada pemilos tahun 2017, calon-calon ketua osis yang berpartisipasi cukup banyak yakni 5 orang. Selain itu komposisi calon berasal dari kelas $\mathrm{X}$ dan XI yang berarti menunjukkan adanya motivasi tinggi dari peserta didik untuk menjadi pemimpin meskipun ada yang baru menginjak tahun pertama di sekolah. Berikutnya adalah persebaran secara gender. Terdapat calon pemimpin perempuan dan laki-laki yang berpartisipasi dalam kegiatan. Maka hal ini membuktikan bahwa proses penyadaran tentang hak terutama bagi pemimpin perempuan cukup berhasil karena orientasi peserta didik cukup beragam serta tidak hanya melihat sudut pandang pemimpin kepada laki-laki.

3. Mengidentifikasi Fungsi Lembaga Negara

Penyelenggaraan negara tidak lepas dari peran lembaga negara yakni pemerintah. Pada proses pembelajaran PPKn di kelas, materi tentang lembaga negara dan proses penyelenggaraan negara adalah hal dasar yang perlu diketahui oleh peserta didik. Hal 
ini tidak lain karena peserta didik pada saatnya nanti akan terjun ke masyarakat dan terlibat dalam proses penyelenggaraan sebuah sistem pemerintahan baik di skala kecil maupun besar. Melalui pemilos, peserta didik mendapatkan pengalaman nyata terkait proses penyelenggaraan pemilihan umum di tingkat sekolah. Peserta didik secara independen menciptakan dan menjalankan sebuah sistem yang mereka susun. Maka hal ini jelas, pemilos memberikan pengetahuan dan pengalaman bagi peserta didik untuk menyadari fungsi dan peran lembaga dalam sebuah sistem seperti layaknya lembaga negara dalam sebuah negara. Peserta didik mampu mengidentifikasi dan menemukan berbagai fungsi lembaga negara serta pelaksanaannya.

\section{Pendekatan Kurikulum 2013 pada Pembelajaran PPKn melalui Pemilos}

Pada pembahasan ini merupakan pembahasan tambahan terkait pemilos di SMK N 1 Pandak. Seperti kita tahu bahwa proses pemilos tidak hanya dipandang sebagai sebuah mekansime prosedural yang harus dilakukan oleh peserta didik di sekolah. Namun pemilos merupakan sebuah wujud pengembangan pendidikan yang dapat dilakukan oleh guru di sekolah. Hal ini juga sesuai dengan kurikulum yang saat ini dikembangkan dalam proses pendidikan yakni Kurikulum 2013. Pembelajaran PPKn dengan pendekatan ilmiah sesuai dengan kurikulum 2013 dikembangkan untuk dapat mengoptimalkan pengetahuan, pengalaman dan keterampilan peserta didik. Maka capaian pembelajaran ditekankan pada 3 aspek yakni kognitif, afektif, dan psikomotorik. Berikut beberapa analisis terkait pendekatan kurikulum 2013 dalam pembelajaran PPKn melalui pemilos.

Pertama, melalui pemilos terjadi proses pendidikan yang mengembangkan kemampuan berpikir tingkat tinggi (Higher Order Thinking Skill) bagi peserta didik. Dalam proses pembelajaran di kelas peserta didik menggali pengetahuan, mendiskusikan pemahaman, melakukan penggalian informasi melalui berbagai kajian tentang kepemimpinan, hak dan kewajiban warga negara, lembaga negara dan lain sebagainya. Melalui pengetahuan yang dipelajari di kelas bersama guru dan rekan-rekan yang lain peserta didik memahami materi kewarganegaraan dan Pancasila. Pada tahap selanjutnya peserta didik dapat menerapkan dan menganalisis proses penyelenggaraan pemilos sesuai dengan kebutuhan mereka. Hingga pada akhirnya peserta didik mampu melaksanakan dan mengevaluasi kegiatan pemilos yang mereka kerjakan bersama teman-temannya. Pada proses ini sebenarnya terjadi sebuah pendekatan ilmiah (scientific learning) yang dilakukan oleh peserta didik dan guru. Guru menjadi fasilitator bagi peserta didik untuk menemukan pengetahuan baru yang ditemukan di lapangan.

Kedua, model pembelajaran yang dikembangkan melalui pemilos dapat dikatakan sebagai bentuk Pembelajaran Berbasis Proyek (Project Based Learning). Melalui pemilos, peserta didik mempraktekkan, menemukan, menguji dan pada akhirnya dapat menemukan bentukbentuk pengetahuan dan pengalaman yang diperoleh sebelumya di dalam kelas. Terdapat penempatan aspek pengetahuan, pemahaman, pengalaman, keterampilan dan unjuk kerja peserta didik sebagai satu proses yang terintegrasi untuk mencapai tujuan pembelajaran.

Ketiga, pengembangan kecakapan peserta didik melalui pemilos. Sebagaimana kita pahami bersama bahwa dalam pengembangan K13 menuntut pengembangan kecakapan atau kemampuan peserta didik yang tidak hanya diperoleh melalui materi di kelas namun melalui aktivitas. Maka dengan pemilos, berbagai materi kewarganegaraan, Pancasila dan kepemimpinan yang diperoleh dalam pembelajaran PPKn di kelas kemudian dijalankan melalui aktivitas peserta didik. Oleh sebab itu melalui kegiatan pemilos kemampuan berpikir kritis, kemampuan memecahkan masalah, kreativitas, inovasi, kemampuan komunikasi, dan kemampuan kolaborasi peserta didik telah terbangun. Peserta didik mencermati, mengkritisi dan 
menyelesaikan persoalan dalam melaksanakan proses pemilos. Peserta didik belajar berkomunikasi dan berkolaborasi dengan guru serta KPU, dan lain sebagainya.

Keempat, pemilos sebagai sarana pembelajaran yang mampu menguatkan pendidikan karakter. Hal ini juga tertuang jelas dalam pendekatan kurikulum 2013 bahwa Penguatan Pendidikan Karakter harapannya terintegrasi dalam proses pembelajaran. Hal ini sesuai dengan Peraturan Presiden No 87 tahun 2017 yang menyebutkan tentang 18 butir nilai karakter. Pelaksanaannya dapat dilakukan dalam kegiatan intrakurikuler, kokurikuler, dan ekstrakurikuler. Maka dalam proses pemilos peserta didik sebenarnya telah mempraktekkan dan melaksanakan implementasi nilai-nilai karakter diantaranya nasionalisme, integritas, mandiri, gotorng royong, keadilan, kejujuran, dan lain sebagainya.

\section{SIMPULAN}

Pemilos di SMK N 1 Pandak dilaksanakan sebagai sebuah sarana pembelajaran bagi peserta didik untuk memahami kesadaran berkonstitusi dalam posisinya sebagai warga sekolah dan bagian dari warga negara. Pemilos di SMK N 1 Pandak dilaksanakan dengan melibatkan berbagai elemen sekolah yakni peserta didik, guru dan fasilitas sekolah. Guru PPKn memainkan peran vital dalam proses penyelenggaraan pemilos di SMK $\mathrm{N} 1$ Pandak. Pada proses pemilos di SMK N 1 Pandak, guru PPKn mengedepankan prinsipprinsip pembelajaran yakni 1) upaya menyampaikan pengetahuan tentang Pancasila dan Kewarganegaraan kepada peserta didik di sekolah; 2) pewarisan kebudayaan yang memuat nilai-nilai karakter kejujuran, keadilan, toleransi, penghargaan, mengakui hak dan kewajiban kepada generasi muda melalui lembaga pendidikan sekolah; 3) upaya mengorganisasikan lingkungan untuk menciptakan kondisi belajar bagi peserta didik melalui dukungan penyelenggaraan pemilos; 4) upaya mempersiapkan peserta didik menjadi warga negara yang baik untuk terlibat aktif dalam proses menentukan pemimpin; 5) proses membantu peserta didik menghadapi kehidupan sehari-hari sebagai warga negara. Selanjutnya guru PPKn menerjemahkan pemilos di SMK N 1 Pandak sebagai sarana inovasi model pembelajaran bagi guru dan peserta didik. Hal ini dirumuskan dalam tiga langkah yakni orientasi, implementasi dan capaian pembelajaran. Implementasi pembinaan kesadaran berkonstitusi bagi peserta didik dapat ditunjukkan melalui kegiatan pemilos di SMK N 1 Pandak. Berbagai bentuk praktek kesadaran berkonstitusi dapat ditunjukkan dengan penyadaran hak dan kewajiban warga negara, proses menentukan pemimpin, dan mengidentifikasi fungsi lembaga negara. Selain itu pemilos dapat ditelaah dalam sebuah kajian tentang bentuk pembelajaran PPKn dengan menggunakan pendekatan Kurikulum 2013. Pembelajaran PPKn dengan pendekatan ilmiah sesuai dengan kurikulum 2013 dikembangkan untuk dapat mengoptimalkan pengetahuan, pengalaman dan keterampilan peserta didik. Pertama, melalui pemilos terjadi proses pendidikan yang mengembangkan kemampuan berpikir tingkat tinggi (Higher Order Thinking Skill) bagi peserta didik. Dalam proses pembelajaran di kelas peserta didik menggali pengetahuan, mendiskusikan pemahaman, melakukan penggalian informasi melalui berbagai kajian tentang kepemimpinan, hak dan kewajiban warga negara, lembaga negara dan lain sebagainya. Kedua, Pendekatan ilmiah (scientific learning) yang dilakukan oleh peserta didik dan guru menjadikan guru sebagai fasilitator bagi peserta didik untuk menemukan pengetahuan baru yang ditemukan di lapangan melalui pemilos. Ketiga, model pembelajaran yang dikembangkan melalui pemilos dapat dikatakan sebagai bentuk Pembelajaran Berbasis Proyek (Project Based Learning). Melalui pemilos, peserta didik 
mempraktekkan, menemukan, menguji dan pada akhirnya dapat menemukan bentukbentuk pengetahuan dan pengalaman yang diperoleh sebelumya di dalam kelas. Keempat, pengembangan kecakapan peserta didik melalui pemilos. Kemampuan berpikir kritis, kemampuan memecahkan masalah, kreativitas, inovasi, kemampuan komunikasi, dan kemampuan kolaborasi peserta didik telah terbangun melalui pemilos. Kelima, pemilos sebagai sarana pembelajaran yang mampu menguatkan pendidikan karakter. Dalam proses pemilos peserta didik telah mempraktekkan dan melaksanakan implementasi nilai-nilai karakter diantaranya nasionalisme, integritas, mandiri, gotorng royong, keadilan, kejujuran, dan lain sebagainya.

\section{UCAPAN TERIMA KASIH}

Penulis mengucapkan terima kasih kepada civitas akademik di SMK N 1 Pandak Bantul yang telah membantu proses penelitian. Penulis juga mengucapkan terima kasih kepada MGMP PPPKn Kabupaten Bantul yang selalu memberikan motivasi bagi guru-guru PPPKn di Kabupaten Bantul untuk selalu berkarya. Kami ucapkan terima kasih juga kepada redaksi Socia yang telah mempublikasikan artikel hasil penelitian ini sehingga penelitian ini dapat dibaca oleh berbagai kalangan. Hasil penelitian ini pastinya masih dapat dikembangkan ke dalam penelitian lain. Harapannya penelitian ini menjadi referensi penelitian selanjutnya. Semoga hasil penelitian ini bermanfaat bagi perkembangan ilmu pengetahuan. Semoga teman-teman guru semakin kreatif dalam membuat karya penelitian.

\section{DAFTAR PUSTAKA}

Budiardjo, Miriam.(2016). Dasar-Dasar Ilmu Politik. Jakarta : Kompas Gramedia.
Daryanto.(2015). Pengelolaan Budaya dan Iklim Sekolah. Yogyakarta : Gava Media.

Hamalik, Oemar.(2010). Kurikulum dan Pembelajaran. Jakarta : Bumi Aksara.

Januarti，Nur Endah.(2016). Orientasi dan Partisipasi Politik Pemilih Pemula dalam Pemilu Legislatif 2014. Jurnal JIPSINDO, Nomor 2 Volume 3, September 2016, pp $92-114$.

KPU Bantul.(2017). Buku Panduan Pemilos 2017. Bantul : KPU.

Penyelenggaraan, Tahapan, dan Teknis Pemilos. Materi TOT Pemilos tahun 2017. Komisioner KPU Kabupaten Bantul periode 2013 2018.

Mahkamah Konstitusi.(2018). Pedoman Anugerah Konstitusi tahun 2018 Bagi Guru PPKn Berprestasi Tingkat Nasional. Jakarta.

Mulyasa.(2007). Menjadi Guru Profesional : Menciptakan Pembelajaran Kreatif dan Menyenangkan. Bandung : Rosdakarya.

Peraturan Presiden No 87 tahun 2017 tentang Penguatan Pendidikan Karakter.

Rohmadi, Muhammad.(2012). Menjadi Guru Profesional dan Berkarakter. Surakarta: Yuma Pustaka.

Sagala, Syaiful.(2013). Etika dan Moralitas Pendidikan. Jakarta : Prenadamedia Group.

Surbakti, Ramlan.(2007). Memahami Ilmu Politik. Jakarta : Gramedia.

Undang-Undang Nomor 14 tahun 2005 tentang Guru dan Dosen. 
Undang-Undang Nomor 20 tahun 2003 tentang Sistem Pendidikan Nasional.

Undang-Undang Nomor 40 tahun 2009 tentang Pemilu. 